\title{
Seroprevalence and Identification of Ornithobacterium rhinotracheale from Broiler and Broiler Breeder Flocks in Thailand
}

\author{
Niwat Chansiripornchai, ${ }^{\mathrm{AB}}$ Wisanu Wanasawaeng, ${ }^{\mathrm{C}}$ and Jiroj Sasipreeyajan ${ }^{\mathrm{A}}$ \\ ${ }^{A}$ Department of Veterinary Medicine, Faculty of Veterinary Science, Chulalongkorn University, Bangkok 10330, Thailand \\ ${ }^{\mathrm{C}}$ Sahafarm Co. Ltd., Lopburi, Thailand
}

Received 9 October 2006; Accepted 21 March 2007

SUMMARY. Ornithobacteriosis is an infectious disease of avian species that has been reported in almost all countries around the world, except Thailand. The objectives of this study were to determine the seroprevalence of Ornithobacterium rhinotracheale (ORT) and to isolate and identify ORT in broilers and broiler breeders in Thailand. Chicken antibodies had been randomly checked from 17 farms (19 flocks) of broilers and 23 farms ( 28 flocks) of broiler breeders. The seropositive flocks were $63 \%$ and $100 \%$ in broilers and broiler breeders, respectively. The sera analysis showed that the individual 280 broiler sera antibody responses were $67.5 \%$ negative, $12.9 \%$ suspected, and $19.6 \%$ positive. The individual antibody responses of 510 broiler breeder sera revealed $12.2 \%$ negative, $38.0 \%$ suspected, and $49.8 \%$ positive samples. The bacteria were isolated and identified by polymerase chain reaction (PCR). Bacterial isolation and identification revealed that nine isolates of the $12 \mathrm{PCR}$ analysis samples showed positive results to PCR analysis. All the positive PCR samples were collected from the broiler breeder farms.

RESUMEN. Nota de Investigación-Seroprevalencia e identificación de Ornithobacterium rhinotracheale a partir de pollos y reproductoras de engorde en Tailandia.

La Ornithobacteriosis es una enfermedad infecciosa de las especies aviares que se ha reportado en casi todos los países del mundo con la excepción de Tailandia. Los objetivos de este estudio fueron determinar la seroprevalencia del Ornithobacterium rhinotracheale (por sus siglas en Inglés ORT), lo mismo que aislar e identificar el ORT en pollos y reproductoras de engorde en Tailandia. La presencia de anticuerpos fue evaluada aleatoriamente en 17 granjas de pollos de engorde y en 32 granjas de reproductoras de engorde. Se encontró una positividad del $63 \%$ en los pollos y del $100 \%$ en la reproductoras. Los análisis del suero mostraron que de las 280 muestras de suero de pollos, el 67.5\% fueron negativas, el 12.9\% sospechosas y el 19.6\% positivas. Las respuestas individuales de anticuerpos de 510 muestras de suero de reproductoras de engorde mostraron que el $12.2 \%$ fueron negativas, el $38.0 \%$ sospechosas y el $49.8 \%$ positivas. La bacteria fue aislada y identificada por medio de la reacción en cadena por la polimerasa. El aislamiento y identificación de las bacterias mostró que de 12 muestras analizadas, nueve fueron identificadas como positivas. Todas las muestras positivas fueron obtenidas de las granjas de reproductoras de engorde.

Key words: seroprevalence, Ornithobacterium rhinotracheale, PCR, chickens

Abbreviations: $\mathrm{ELISA}=$ enzyme-linked immunosorbent assay; $\mathrm{ORT}=$ Ornithobacterium rhinotracheale; $\mathrm{PCR}=$ polymerase chain reaction

A major problem of the poultry industry around the world is respiratory tract infection, which creates a major economic impact due to the increase in treatment cost and losses through the deaths of animals and higher condemnation rates. Respiratory diseases of poultry arise from the various causes, including bacteria (9), viruses (2), and fungi (1). Ornithobacterium rhinotracheale (ORT) is the recently described species of bacterium that is a slow growing, gramnegative, pleomorphic bacterium (29). Up to now, at least 18 serotypes of ORT could be distinguished (30). Serotyping in chickens has revealed that the majority of isolates are of serotype A and that $95 \%$ of strains belong to the four major serotypes $\mathrm{A}, \mathrm{B}, \mathrm{D}$, and $\mathrm{E}$. Turkey isolates seemed to be more heterogeneous, being distributed among the serotypes (32). ORT causes respiratory tract infection in many avian species $(19,34)$, which can be isolated from the air sacs and pneumonic lesions of poultry around the world $(19,24,25,28,30)$. Also, the bacteria can be isolated in many avian species, including peacocks, ostriches, quails, guinea fowls, and ducks $(10,12,29,30,32)$. The disease was first discovered in 1991 by Jan DuPreez (28). ORT can be a primary or secondary etiologic agent depending on strain virulence, adverse environmental factors, the immune state of the flock, and the presence of other infectious agents (30). ORT can cause highly contagious diseases in poultry, although the severity of the

${ }^{\text {B } C o r r e s p o n d i n g ~ a u t h o r . ~ E-m a i l: ~ c n i w a t @ c h u l a . a c . t h ~}$ clinical signs, the duration of the disease, and mortality have been found to be extremely variable (30). Losses of $5 \%-10 \%$ are frequently seen, and even losses up to $90 \%$ are not rare from this disease (33). In Hungary, substantial mortality $(0.5 \%-2 \%$ per day) associated with ORT infection in 4- to 6-wk-old broiler flocks has been reported (23). Gross pathologic lesions usually include serous-catarrhal inflammation of the mucous membrane in the upper respiratory tract with less often unilateral or bilateral pneumonia, as well as serofibrinous airsacculitis and pericarditis (11). ORT infections have been reported in many countries around the world, including Belgium (35), Canada (17), the United States (10), France (18), Israel (7), England (4), Slovenia (37), Mexico (22), Peru (16), Korea (36), Japan (28), Jordan (13), Turkey (14,27), Egypt (12), and Taiwan (26). In Thailand, ORT isolation has not been reported yet. In addition, serologic evidence of ORT infection has been obtained (4) and the presence of ORT can be confirmed from maternal immunity derived from the infected chickens. The aim of this study was to determine the prevalence of ORT infection and also to isolate and identify ORT in broilers and broiler breeders in Thailand, which is the first step necessary before control measures can be implemented.

\section{MATERIALS AND METHODS}

Broiler and broiler breeder serum samples. Serum samples were collected from the 17 broiler farms (19 flocks) and 23 broiler breeder 
Table 1. ELISA results of ORT from broiler farms.

\begin{tabular}{|c|c|c|c|c|c|c|}
\hline \multirow[b]{2}{*}{ Farm code } & \multirow[b]{2}{*}{ Province } & \multirow[b]{2}{*}{ Age (days) } & \multirow[b]{2}{*}{ No. of samples } & \multicolumn{3}{|c|}{ ELISA results } \\
\hline & & & & Negative & Suspect & Positive \\
\hline Vet-24 & Phetchabun & 40 & 12 & 1 & 2 & 9 \\
\hline Vet-25 & Burirum & 44 & 10 & 0 & 2 & 8 \\
\hline Vet-26 & Chaiyaphum & 42 & 10 & 0 & 8 & 2 \\
\hline Vet-27 & Lopburi & 42 & 10 & 0 & 1 & 9 \\
\hline Vet-28.1 & Lopburi & 42 & 10 & 1 & 2 & 7 \\
\hline Vet-28.2 & Lopburi & 41 & 10 & 0 & 4 & 6 \\
\hline Vet-29 & Lopburi & 42 & 10 & 3 & 4 & 3 \\
\hline Vet-30 & Chainart & 45 & 10 & 10 & 0 & 0 \\
\hline Vet-31 & Lopburi & 42 & 10 & 10 & 0 & 0 \\
\hline Vet-32 & Chaiyaphum & 42 & 10 & 10 & 0 & 0 \\
\hline Vet-33 & Lopburi & 42 & 10 & 9 & 1 & 0 \\
\hline Vet-34 & Lopburi & 42 & 10 & 9 & 0 & 1 \\
\hline Vet-35 & Lopburi & 42 & 10 & 8 & 1 & 1 \\
\hline Vet-36 & Chonburi & 42 & 30 & 18 & 8 & 4 \\
\hline Vet-37. $1^{\mathrm{A}}$ & Chonburi & 39 & 25 & 21 & 1 & 3 \\
\hline Vet-37.2 & Chonburi & 40 & 25 & 24 & 1 & 0 \\
\hline Vet-38 & Chonburi & 39 & 25 & 25 & 0 & 0 \\
\hline Vet-39 ${ }^{\mathrm{A}}$ & Chonburi & 39 & 23 & 22 & 1 & 0 \\
\hline \multirow[t]{3}{*}{ Vet-40 } & Chonburi & 30 & 20 & 18 & 0 & 2 \\
\hline & & Total & 280 & 189 & 36 & 55 \\
\hline & & $\%$ & $100 \%$ & 67.5 & 12.9 & 19.6 \\
\hline
\end{tabular}

${ }^{\mathrm{A}}$ The isolates from these farms revealed negative results, which were tested by PCR.

farms (28 flocks) of the major producing companies of Thailand (Tables 1,2) in the period between October 2004 and September 2005 and kept at $-20 \mathrm{C}$ until tested.

Enzyme-linked immunosorbent assay (ELISA). Sera were analyzed by indirect ELISA with an ORT antibody test kit (Biochek, Gauda, the Netherlands) that detects antibodies against serotypes A to M. Optical densities were determined in an ELISA reader and processed with software from Biochek. According to the test, three categories of the results had been established. The negative, suspect, and positive results are in the titer range $\leq 424,425-1431$ and $\geq 1432$, respectively.

Isolation of bacteria. The bacteria were collected from chickens in the seropositive flocks. In each flock, the tracheas of 20 mild clinically ill birds (coughing or sneezing) had been swabbed from a flock of approximately $25,000 \mathrm{birds}$, and five samples had been pooled to one sample. Additionally, the severe clinically ill birds (nasal discharge,

4 severe coughing, no appetite, or severe depress) were be necropsied and the trachea or air sacs had been swabbed and pooled as described previously. To accomplish this, the sterile swabs were inserted approximately $2.5 \mathrm{~cm}$ into the trachea and carefully withdrawn to avoid contamination from the pharyngeal region. The swabs were placed in sterile tube with tryptone soya agar (Oxoid, Hampshire, England), capped, and cooled transported within 2 days to the laboratory. The bacteria were cultured in a Columbia agar base with $5 \%$ sheep blood and $5 \mu \mathrm{g} / \mathrm{ml}$ gentamicin under microaerophilic conditions, for $48-72 \mathrm{hr}$. After incubation, colonies that were pinpoint, circular, opaque to grayish, and nonhemolytic were considered to be suspect (31). Gramnegative, catalase-negative, and oxidase-positive colonies were tested before identification by polymerase chain reaction (PCR).

PCR analysis. Primers used in this study were OR16S-F1 (5'GAGAATTAA TTTACGGATTAAG-3') and OR16 S-R1 (5'TTCGCTTGGTCTCCGAAGAT-3'), which were very specific in amplifying a 784-base pair fragment of the $16 \mathrm{~S}$ rRNA gene of ORT, but not of other closely related bacteria (30). Bacterial DNA was extracted and purified by DNA trap (Biotec, Bangkok, Thailand). PCR was conducted in a Thermal Cycler (MyCyler ${ }^{(m)}$; Bio-Rad). A reaction volume of $20 \mu \mathrm{l}$ contained $10 \times \mathrm{PCR}$ buffer with $\left(\mathrm{NH}_{4}\right)_{2} \mathrm{SO}_{4}, 2.5 \mathrm{mM}$ $\mathrm{MgCl}_{2}, 0.2 \mathrm{mM}$ dNTP, $1.0 \mu \mathrm{M}$ each primer, $50-100 \mathrm{ng}$ of DNA template, and $1.5 \mathrm{U}$ of Taq DNA polymerase. Samples were subjected to $94 \mathrm{C}, 90 \mathrm{sec}$ followed by 35 cycles at $58 \mathrm{C}, 60 \mathrm{sec}$ and $72 \mathrm{C}, 90 \mathrm{sec}$. PCR products were examined in $1.8 \%$ agarose gels with a $0.5 \times$ Tris
borate-EDTA buffer, stained with $10 \mu \mathrm{l}$ of ethidium bromide $(20 \mathrm{mg} /$ $\mathrm{ml})$, and exposed to ultraviolet light.

\section{RESULTS}

ELISA. The ELISA results for the chickens from 40 farms ( 47 flocks) were revealed. The results showed that 12 of the 19 (63\%) broiler flocks were ORT antibody positive. All broiler breeder flocks were ORT antibody positive. The ELISA results from 17 broiler farms for those ages between 30 and 45 days were $67.5 \%$ negative, $12.9 \%$ suspected, and $19.6 \%$ positive (Table 1 ). The ELISA results for 23 broiler breeder farms for those ages between 17 and 62 weeks were $12.2 \%$ negative, $38.0 \%$ suspected, and $49.8 \%$ positive (Table 2). ORT vaccines have never been used in Thailand; so, the suspected results may be regarded as positive results. The suspected + positive results in the broiler farms were $32.5 \%$. The suspected + positive ELISA results in the broiler breeder farms were $87.8 \%$, and older birds were more positive than younger birds.

Isolation of ORT. In total, 165 pooled samples were obtained from 51 broiler flocks and 114 pooled samples from broiler breeder flocks. Thirty-seven suspected bacterial samples $(22.4 \%$ of the total submitted pooled samples) could be grown and isolated. Twelve (three and nine isolates from broiler and broiler breeder flocks, respectively) (32.4\% of the cultured isolates) of the 37 isolates, revealed gram-negative stain, positive to catalase, and negative to oxidase. The rest of bacteria (25 strains) were kept for further identification.

PCR analysis. The PCR analysis revealed nine positive samples from 12 ORT suspected samples of the seroconversion flocks. All PCR-positive samples were isolated from the broiler breeder flocks (Table 2).

\section{DISCUSSION}

Our work is the first report of the seroprevalence and the presence of ORT in Thailand within the commercial broiler and broiler 
Table 2. ELISA results of ORT from broiler breeder farms and the PCR results of ORT tested from the gram-negative, catalase positive and oxidase negative bacterial colonies.

\begin{tabular}{|c|c|c|c|c|c|c|}
\hline \multirow[b]{2}{*}{ Farm code } & \multirow[b]{2}{*}{ Province } & \multirow[b]{2}{*}{ Age (wk) } & \multirow[b]{2}{*}{ No. of samples } & \multicolumn{3}{|c|}{ ELISA results } \\
\hline & & & & Negative & Suspect & Positive \\
\hline Vet-1.1 & Prachinburi & 21 & 10 & 0 & 0 & 10 \\
\hline Vet-1.2 & Prachinburi & 21 & 10 & 0 & 0 & 10 \\
\hline Vet-2 & Phetchabun & 26 & 12 & 2 & 5 & 5 \\
\hline Vet-3 & Phetchabun & 36 & 10 & 4 & 5 & 1 \\
\hline Vet-4 & Lopburi & 27 & 10 & 1 & 4 & 5 \\
\hline Vet-5 & Lopburi & 29 & 27 & 11 & 13 & 3 \\
\hline Vet-6 & Lopburi & 31 & 25 & 8 & 12 & 5 \\
\hline Vet-7 & Lopburi & 30 & 38 & 3 & 16 & 19 \\
\hline Vet-8 & Lopburi & 17 & 30 & 14 & 13 & 3 \\
\hline Vet-9 & Lopburi & 46 & 24 & 1 & 13 & 10 \\
\hline Vet-10 ${ }^{\mathrm{A}}$ & Chonburi & 36 & 30 & 1 & 11 & 18 \\
\hline Vet-11 & Chonburi & 22 & 12 & 0 & 6 & 6 \\
\hline Vet-12 & Chonburi & 53 & 12 & 2 & 4 & 6 \\
\hline Vet-13 & Chonburi & 58 & 11 & 2 & 5 & 4 \\
\hline Vet-14 & Chonburi & 43 & 12 & 0 & 1 & 11 \\
\hline Vet-15 & Chonburi & 32 & 12 & 0 & 3 & 9 \\
\hline Vet-16 & Chonburi & 60 & 12 & 1 & 2 & 9 \\
\hline Vet-17 & Chonburi & 38 & 11 & 1 & 5 & 5 \\
\hline Vet-18 & Chonburi & 44 & 12 & 2 & 2 & 8 \\
\hline Vet-19.1 & Chonburi & 61 & 25 & 0 & 9 & 16 \\
\hline Vet- $19.2^{\mathrm{A}}$ & Chonburi & 48 & 25 & 4 & 12 & 9 \\
\hline Vet- $19.3^{\mathrm{A}}$ & Chonburi & 47 & 22 & 3 & 14 & 5 \\
\hline Vet-20.1 ${ }^{\mathrm{A}}$ & Chonburi & 60 & 15 & 1 & 5 & 9 \\
\hline Vet-20.2 $2^{\mathrm{A}}$ & Chonburi & 59 & 15 & 0 & 4 & 11 \\
\hline Vet-21.1 & Chonburi & 61 & 20 & 1 & 9 & 10 \\
\hline Vet-21.2 & Chonburi & 62 & 19 & 0 & 6 & 13 \\
\hline Vet-22 $2^{\mathrm{A} *}$ & Chonburi & 61 & 25 & 0 & 11 & 14 \\
\hline \multirow[t]{3}{*}{ Vet-23 ${ }^{\mathrm{A}}$} & Chonburi & 61 & 24 & 0 & 4 & 20 \\
\hline & & Total & 510 & 62 & 194 & 254 \\
\hline & & $\%$ & 100 & 12.2 & 38.0 & 49.8 \\
\hline
\end{tabular}

${ }^{\mathrm{A}}$ Isolates from these farms revealed positive results, which were tested by PCR.

breeder population. We found that the antibody against ORT was common even though ORT vaccines have never been applied in Thailand. Herein, the ELISA test revealed that broiler breeder flocks had a greater serologic prevalence for ORT than did broilers. All broiler breeder flocks tested were positive for the ORT antibody, and this was similar to the $100 \%$ positive flocks found in southern Brazil (8) and higher than the $79 \%$ found in broiler breeder flocks in Germany (15). In broiler flocks, 68\% (13/19) had been found positive, and this was higher than the $60 \%$ positive flock found in southern Brazil (8) and the $26 \%$ found in broiler flocks in Germany (20). The high prevalence of positive broiler flocks may be because of the continuous introduction of the agent from their parent flocks $(6,30)$. The results revealed that age might influence the seroprevalence of ORT in Thailand. The broiler chickens, raised over a short period, had been found to display seroconversion to a lesser degree than those of the broiler breeder raised over a longer period. The sera analysis revealed that in the individual 510 broiler breeder sera, $87.8 \%$ were positive, which was lower than the $94.6 \%$ found in broiler breeders in southern Brazil (8) and higher than the $13.9 \%$ found in broiler breeders in Japan (21). Overall, these numbers show a high prevalence of ORT antibodies in broiler breeders in Thailand. The prevalence of the individual 280 broiler sera, $32.5 \%$, that were positive was much greater than the $6.52 \%$ found in broilers in southern Brazil (8) and the $9.4 \%$ found in broilers in Germany (20). The higher prevalence of serum-positive broiler breeders may be the result of a higher challenge and longer life span of breeders. The presence of antibodies and ORT organisms identified in the broiler breeders may lead to the transmission of the bacteria to broilers through the eggs (5). In contrast, serum-positive breeders may passively protect their progeny at the beginning of their life (30), although broilers may become susceptible to clinical disease sometime later (19). The lower prevalence of ORT antibodies in broilers in Thailand, compared with broiler breeders, may be influenced by differences in age, environmental factors, and local strains of the bacteria that spread slowly. All these results might suggest that the rolling infection had been occurring in the broiler and broiler breeder farms. Bacterial isolation and identification revealed that nine isolates of the 12 PCR analysis samples revealed positive results to PCR analysis. All the positive PCR samples that were collected from the broiler breeder farms suggested that age might be an influence on the positive ORT isolation. Our study shows that the prevalence of ORT antibodies and ORT organisms is present in the commercial broiler and broiler breeder population, even though no ORT vaccine had been used in Thailand, suggesting that rolling infection may occur and that the organism can spread through parent flocks to newly housed pullet flocks.

\section{REFERENCES}

1. Akan, M., R. Haziroglu, Z. Ilhan, B. Sareyyupoglu, and R. Tunca. A case of aspergillosis in a broiler breeder flock. Avian Dis. 46:497-501. 2002.

2. Alexander, D. J. Newcastle disease and other avian paramyxoviruses. Rev. Sci. Tech. 19:443-462. 2000. 
3. Amonsin, A., J. F. Wellehan, L. L. Li, P. Vandamme, C. Lindeman, M. Edman, R. A. Robinson, and V. Kapur. Molecular epidemiology of Ornithobacterium rhinotracheale. J. Clin. Microbiol. 35:2894-2988. 1997.

4. Arns, C. W., H. M. Hafez, T. Yano, M. C. G. B. Monteiro, M. Celestino Alves, G. Domingues, and L. T. Coswig. Ornithobacterium 7 rhinotracheale: detecção sorológica em aves matrizes e frangos de corte. In: 8 Proc. Conferência Apinco, Campinas, Brazil. p. 55. 1998.

5. Back, A., Gireesh, R., Halvorson, D. A., and K. V. Nagaraja. Experimental studies of Ornithobacterium rhinotracheale (ORT) infection. In: Proc. 46th Western Poultry Disease Conference, Sacramento, CA. pp. 7-8. 1996.

6. Back, A., G. Rajashekara, R. B. Jeremiah, D. A. Halvorson, and K. V. Nagaraja. Tissue distribution of Ornithobacterium rhinotracheale in experimentally infected turkeys. Vet. Rec. 143:52-53. 1998.

7. Bock, R., P. Freidlin, S. Tomer, M. Manoim, A. Inbar, A. Frommer, P. Vandamme, P. Wilding, and D. Hickson. Ornithobacterium rhinotracheale (ORT) associated with a new turkey respiratory tract infectious agent. In: Proc. 33rd Annual Convention of the Israel Branch of the World Veterinary Association, Zichron, Israel. pp. 43-45. 1995.

8. Canal, C. W., J. A. Leão, D. J. Ferreira, M. Macagnan, C. T. P. Salle, and A. Back. Prevalence of antibodies against Ornithobacterium rhinotracheale in broilers and breeders in southern Brazil., 731-737. 2003.

9. Chansiripornchai, N., and J. Sasipreeyajan. Efficacy of sarafloxacin in broilers after experimental infection with Escherichia coli. Vet. Res. Commun. 26:255-262. 2002.

10. Charlton, B. R., S. E. Channing-Santiago, A. A. Bickford, C. J. Cardona, R. P. Chin, G. L. Cooper, R. Droual, J. S. Jeffrey, C. U. Meteyer, H. L. Shivaprasad, and R. L. Walker. Preliminary characterization of an pleomorphic gram-negative rod associated with avian respiratory disease. J. Vet. Diagn. Invest. 5:47-51. 1993.

11. Chin, R. P., and R. Droual. Ornithobacterium rhinotracheale infection. In: Diseases of poultry, 10th ed. W. B. Calnek, J. H. Barns, C. W. Beard, L. R. McDougald, and Y. M. Saif, eds. Iowa State University Press, Ames, IA. pp. 1012-1015. 1997.

12. Devriese, L. A., P. De Herdt, and F. Haesebrouck. Antibiotic sensitivity and resistance in Ornithobacterium rhinotracheale strains from Belgian broiler chickens. Avian Pathol. 30:197-200. 2001.

13. El-Sukhon, S. N., A. Musa, and M. Al-Attar. Studies on the bacterial etiology of airsacculitis of broilers in northern and middle Jordan with special reference to Escherichia coli, Ornithobacterium rhinotracheale, and Bordetella avium. Avian Dis. 46:605-612. 2002.

14. Erganis, O., H. H. Hadimli, K. Kav, M. Corlu, and D. A. Ozturk. Comparative study on detection of Ornithobacterium rhinotracheale antibodies in meat-type turkeys by dot immunobinding assay, rapid agglutination test and serum agglutination test. Avian Pathol. 31:201-204. 2002 .

15. Hafez, H. M., and R. Sting. Investigations on different Ornithobacterium rhinotracheale "ORT" isolates. Avian Dis. 43:1-7. 1999.

16. Hung, A. L., and A. Alvarado. Phenotypic and molecular characterization of isolates of Ornithobacterium rhinotracheale from Peru. Avian Dis. 45:999-1005. 2001.

17. Joubert, P., R. Higgins, A. Laperle, I. Mikaelian, D. Venne, and A. Silim. Isolation of Ornithobacterium rhinotracheale from turkeys in Quebec, Canada. Avian Dis. 43:622-626. 1999.

18. Leroy-Sétrin, S., G. Flaujac, K. Thenaisy, and E. Chaslus-Dancla. Genetic diversity of Ornithobacterium rhinotracheale strains isolated from poultry in France. Lett. Appl. Microbiol. 26:189-193. 1998.

19. Roepke, D. C., A. Back, D. P. Shaw, K. V. Nagaraja, S. J. Sprenger, and D. A. Halvorson. Isolation and identification of Ornithobacterium rhinotracheale from commercial turkey flocks in the upper Midwest. Avian Dis. 42:219-221. 1998.

20. Ryll, M., K. H. Hinz, U. Neumann, U. Lohren, M. Sudbeck, and D. Steinhagen. Pilot study on prevalence of the Ornithobacterium rhinotracheale infection in meat-type chickens in northwest Germany. Berl. Muench. Tieraerztl. Wochenschr. 110:267-271. 1997.

21. Sakai, E., Y. Tokuyama, F. Nonaka, S. Ohishi, Y. Ishikawa, M. Tanaka, and A. Taneno. Ornithobacterium rhinotracheale infection in Japan: preliminary investigations. Vet. Rec. 146:502-503. 2000.

22. Soriano, V. E., N. A. Vera, C. R. Salado, R. P. Fernandez, and P. J. Blackall. In vitro susceptibility of Ornithobacterium rhinotracheale to several antimicrobial drugs. Avian Dis. 47:476-480. 2003.

23. Szalay, D., R. Glavits, Cs. Nemes, A. Kosa, and L. Fodor. Clinical signs and mortality caused by Ornithobacterium rhinotracheale in turkey flocks. Acta Vet. Hung. 50:297-305. 2002.

24. Tahseen, A. Ornithobacterium rhinotracheale developing into a serious infection. World Poul. Misset. 13:47-48. 1997.

25. Travers, A. F., L. Coetzee, and B. Gummow. Pathogenicity differences between South African isolates of Ornithobacterium rhinotracheale. Onderstepoort J. Vet. Res. 63:197-207. 1996.

26. Tsai, H. J., and C. W. Huang. Phenotypic and molecular characterization of isolates of Ornithobacterium rhinotrachele from chickens and pigeons in Taiwan. Avian Dis. 50:502-507. 2006.

27. Turan, N., and S. Ak. Investigation of the presence of Ornithobacterium rhinotracheale in chickens in Turkey and determination of the seroprevalence of the infection using the enzyme-linked immunosorbent assay. Avian Dis. 46:442-446. 2002.

28. van Beek, P., P. van Empel, G. van den Bosch, P. K. Storm, J. H. Bongers, and J. H. du Preez. Respiratory problems, growth retardation and arthritis in turkeys and broilers caused by a Pasteurella-like organism: Ornithobacterium rhinotracheale or "Taxon 28. Tijdschr. Diergeneeskd. 119:99-101. 1994.

29. Vandamme, P., P. Segers, M. Vancaneyt, K. van Hover, R. Mutters, J. Hommez, F. Dewirst, B. Paster, K. Kersters, E. Falsen, L. Devrieze, M. Bisgaard, K.-H. Hinz, and W. Mannheim. Description of Ornithobacterium rhinotracheale gen. nov. sp. nov. isolated from the avian respiratory tract. Int. J. System. Bacteriol. 44:24-37. 1994.

30. van Empel, P., and H. Hafez. Ornithobacterium rhinotracheale. Avian Pathol. 28:217-227. 1999.

31. van Empel, P., and H. van den Bosch. Vaccination of chickens against Ornithobacterium rhinotracheale infection. Avian Dis. 40:858-864. 1997.

32. van Empel, P., H. van den Bosch, P. Loeffen, and P. Storm. Identification and serotyping of Ornithobacterium rhinotracheale. J. Clin. Microbiol. 35:418-421. 1997.

33. van Veen, L., E. Gruys, K. Frik, and P. van Empel. Increased condemnation of broilers associated with Ornithobacterium rhinotracheale. Vet. Rec. 147:422-423. 2000a.

34. van Veen, L., P. van Empel, and T. Fabri. Ornithobacterium rhinotracheale, a primary pathogen in broilers. Avian Dis. 44:896-900. 2000b.

35. Wyffels, R., and J. Hommez. Pasteurella anatipestifer isolates from respiratory lesions in partridges kept in captivity (Perdix perdix). Vlaams Dier. Tijdschrift. 59:105-106. 1990.

36. Yoon, J. U., D. W. Lee, H. J. Kwon, Y. K. Ahn, and S. J. Kim. Pathogenicity of Korean isolates of Ornithobacterium rhinotracheale in broiler chickens. In: Proc. American Association of Avian Pathology Annual Meeting, Salt Lake City, UT. p. 29. 2000.

37. Zorman-Rojs, O., I. Zdovc, D. Bencina, and I. Mrzel. Infection of turkeys with Ornithobacterium rhinotracheale and Mycoplasma synoviae. Avian Dis. 44:1017-1022. 2000.

\section{ACKNOWLEDGMENT}

We thank the Faculty of Veterinary Science, Chulalongkorn University 2005, for its research grant endowment. 
Authors Queries

Journal: Avian Diseases

Paper: avdi-51-03-18

Title: Seroprevalence and Identification of Ornithobacterium rhinotracheale from Broiler and Broiler Breeder Flocks in Thailand

Dear Author

During the preparation of your manuscript for publication, the questions listed below have arisen. Please attend to these matters and return this form with your proof. Many thanks for your assistance

\begin{tabular}{|c|c|c|}
\hline $\begin{array}{l}\text { Query } \\
\text { Reference }\end{array}$ & Query & Remarks \\
\hline 1 & $\begin{array}{l}\text { Author: This article has been lightly } \\
\text { edited for grammar, style, and us- } \\
\text { age. Please compare it with your } \\
\text { original document and make } \\
\text { changes on these pages. Please } \\
\text { limit your corrections to substantive } \\
\text { changes that affect meaning. If no } \\
\text { change is required in response to } \\
\text { a question, please write "OK as set" } \\
\text { in the margin. Copy editor }\end{array}$ & \\
\hline 2 & $\begin{array}{l}\text { Author: Please give zip code for } \\
\text { Lopburi, Thailand, in footnote C to } \\
\text { title page. Copy editor }\end{array}$ & \\
\hline 3 & $\begin{array}{l}\text { Author: Please note percentages } \\
\text { are now next to word descriptor for } \\
\text { clarity. Is minor change OK? Copy } \\
\text { editor }\end{array}$ & \\
\hline 4 & $\begin{array}{l}\text { Author: Please clarify "severe de- } \\
\text { press[ion]" as related to appetite or } \\
\text { psychological state? Copy editor }\end{array}$ & \\
\hline 5 & $\begin{array}{l}\text { Author: Please give city and state } \\
\text { abbreviation or country for Bio-Rad. } \\
\text { Copy editor }\end{array}$ & \\
\hline 6 & $\begin{array}{l}\text { Author: Is wording OK for Acknowl- } \\
\text { edgment? Minor edits were made. } \\
\text { Copy editor }\end{array}$ & \\
\hline 7 & $\begin{array}{l}\text { Author: After p. 55, please give } \\
\text { dates for meeting as Mon. X-X, } \\
1998 \text { for Refernce 4. Copy editor }\end{array}$ & \\
\hline 8 & $\begin{array}{l}\text { Author: Please note Arns et al. is } \\
\text { now Reference } 4 ; \text { references } 1-4 \\
\text { have been renumbered in text cita- } \\
\text { tions. Please check these citations } \\
\text { carefully. Copy editor }\end{array}$ & \\
\hline
\end{tabular}




\begin{tabular}{|l|l|l|}
\hline 9 & $\begin{array}{l}\text { Author: After pp. 7-8, please give } \\
\text { dates for meeting as Mon. X-X, } \\
1996 \text { for Reference 5. Copy editor }\end{array}$ & \\
\hline 10 & $\begin{array}{l}\text { Author: After pp. 43-45, please give } \\
\text { dates for meeting as Mon. X-X, } \\
1995 \text { for Reference 7. Copy editor }\end{array}$ & \\
\hline 11 & $\begin{array}{l}\text { Author: Please note Reference 26 } \\
\text { and 27are now reversed in text. }\end{array}$ & $\begin{array}{l}\text { Please check these citations care- } \\
\text { fully. Copy editor }\end{array}$ \\
\hline 12 & $\begin{array}{l}\text { Author: After p. 29, please give } \\
\text { dates for meeting as Mon. X-X, } \\
\text { 2000 for Reference 36. Copy editor }\end{array}$ & \\
\hline
\end{tabular}

